\title{
MAKNA DAN FUNGSI PARIBASA SUNDA (PANGJURUNG LAKU HADÉ)
}

\author{
Embang Logita \\ Program Studi Pendidikan Bahasa dan Sastra Indonesia \\ Universitas Wiralodra \\ E-mail : embanglogita@ rocketmail.com
}

Penelitian ini dilandasi oleh pemikiran bahwa paribahasa Sunda merupakan warisan budaya pemilikmya yaitu masyarakat Sunda yang syarat akan makna yang terkandung didalamnya yang harus kita lestarikan dan kita pakai dalam kehidupan sehari-hari.

Paribasa Suda Paribasa Sunda merupakan salah satu warisan budaya nusantara dengan kata lain paribasa Sunda merupakan salah satu bagian peribahasa yang ada di nusantara. Paribasa Sunda merupakan bahasa perbandingan yang menjadi perlambang kehidupan manusia, yang bahasan dan pengucapannya yang tidak boleh diubah-ubah. Paribasa Sunda merupakan sebuah kalimat. dengan memilik iciri-ciri paribasa sunda antara lain : Paribasa Sunda mempunyai sifat membandingkan, mengumpamakan; merupakan pembicaraan yang artinya bukan yang sebenarnya; berupa kalimat yang dapat membawa perasaan kepada yang orang yang diajak bicara;kalimatnya tidak bisa diubah, dikurangi, ditambah, atau dengan pengucapannya dengan bahasa halus.

Didalam paribasa Sunda dilihat dari maksud dan tujuannya dapat digolongkan menjadi tiga bagian:Paribasa wawaran luang,isinya mengungkapkan pengalaman yang suadah biasa dalam masyarakat, serta merupakan bahan perbandingan untuk tingkah laku kita; paribasa pangjurung laku hade, dimana paribasa ini isinya mengungkapkan untuk melakukan perilaku-perilaku yang baik yang harus dilakukan oleh kita; paribasa panyaram lampah salah dimana isinya mengungkapkan supaya setiap orang jangan melaksanakan kelakuan-kelakuan yang tidak baik.

Paribasa pangjurung laku hade merupakan salah satu paribasa yang didalamnya mempunyai makna-makna dan fungsi tersendiri dalm kehidupan sehari hari

\section{Kata Kunci: Paribasa Sunda (Pangjurung Laku Hadé), Makna Dan Fungsi.}

\section{PENDAHULUAN}

Dalam kurun waktu yang lampau sebelum manusia mengenal tulisan (aksara) segala sesuatunya dilakukan secara lisan termasuk proses pewarisan budaya dan tradisi seperti pewarisan cara hidup, karya sastranya, kepercayaan (religi), upacara adat (ritual), sistem pengetahuan dan sebagainya. Jadi, karena proses pewarisannya secara lisan itulah kemudian dikenal dengan istilah tradisi lisan.

Tradisi lisan merupakan segala bentuk pewarisan adat istiadat yang lahir dari suatu kelompok masyarakat yang disampaikan atau diwariskan secara lisan kepada tiap generasi. Setiap tradisi pastilah memiliki kandungan nilai-nilai makna, dan fungsi bagi masyarakat.

Sastra daerah adalah bagian dari tradisi lisan. Sastra daerah lebih dikenal dengan sastra lisan meliputi prosa dan puisi lisan yang dalam penyampaiannya menggunankan bahasa lisan serta masih menggunakan bahasa daerah. Sastra daerah atau sastra lisan ini hanya dikenal pada masyarakat pemiliknya sehingga hanya populer pada masyarakat pemiliknya juga sehingga tidak begitu dikenal oleh masyarakat luar.

Salah satu bentuk sastra lisan yang ada di setiap daerah adalah ungkapan tradisional atau lebih di kenal dengan nama 
peribahasa. Setiap daerah di Indonesia mempunyai sastra lisan berupa peribahasa yang mempunyai kekhasan masing-masing. Dilihat dari segi bahasa maka sesuai dengan bahasa yang dipunyai oleh daerah tersebut. Peribahasa tidak saja merupakan mutiara bahasa, bunga bangsa, tetapi juga suatu kalimat yang memberikan pengertian yang dalam, luas, dan tepat; disampaikan dengan halus dengan kiasan. Sebagaian peribahasa itu mempunyai nilai yang universal dan berlaku untuk semua orang dan segala jaman (Edwar Djamaris, 1993)

Salah satu ungkapan tradisional atau peribahasa juga berkembang di tatar Sunda, peribahasa yang ada di tatar Sunda dinamakan paribasa Sunda. Paribasa Sunda merupakan sebuah kalimat (klausa) yang pengucapan dan susunan dan maksudnya sudah pasti biasanya mempunyai arti sebagai perbandingan dan penjabaran dalam kehidupan manusia. Paribasa Sunda digolongkan menjadi tiga bagian yaitu paribasa Sunda pangjurung laku hadé, paribasa Sunda panyaram lampah dan paribasa Sunda wawaran luang. Kita sebagai generasi harus dapat mengetahui, memahami makna, harus bisa meneliti sampai hal-hal yang berhubungan dengan strukturnya, konteks penuturan, proses penciptaan dan fungsi yang terkandung didalamnya sehingga paribasa Sunda ini tetap lestari dan ada.

Dari permasalahan penulis akan meneliti tentang "Makna dan Fungsi Paribasa Sunda (Pangjurung Laku Hadé).

\section{Batasan Masalah}

Agar penulisan lebih spesifik dan dapat dilaksanakan sesuai dengan kemampuan penulis, maka masalah yang akan dikaji harus dibatasi secara jelas. Penelitian ini dibatasi sebagai berikut :

1. Struktur teks yang terdapat dalam paribasa Sunda (pangjurung laku hadé).

2. Makna yang terkandung dalam paribasa Sunda (pangjurung laku hadé).
3. Fungsi yang terkandung dalam paribasa Sunda (pangjurung laku hadé).

\section{Rumusan Masalah}

Agar penulisan ini berjalan dengan baik, maka berdasarkan batasan masalah di atas, penulis membuat rumusan masalah sebagai berikut :

1. Bagaimana makna dari paribasa Sunda(pangjurung laku hadé)?

2. Bagaimana fungsi dari paribasa Sunda(pangjurung laku hadé) sebagai bentuk kearifan lokal yang berkembang dalam kehidupan masyarakat?

\section{Tujuan Penelitian}

Dari uraian latarbelakang dan rumusan masalah di atas, maka penelitian ini bertujuan :

1. mendapat gambaran makna yang terkadung dalam paribasa Sunda(pangjurung laku hadé) sebagai bentuk kearifan lokal berkembang dalam kehidupan masyarakat.

2. mendapat gambaran mengenai fungsi dari paribasa Sunda (pangjurung laku hadé).

\section{Manfaat Penelitian}

Adapun manfaat yang diharapkan dari penelitian ini adalah memberikan manfaat baik secara teoritis maupun praktis. Secara teoritis adalah dapat mengetahui perkembangan paribasa Sunda dilihat dari segi makna dan fungsidengan baik dan benar, Secara praktis yaitu lebih luas lagi dalam mengenal paribasa Sunda.

\section{LANDASAN TEORI \\ Folklor}

Folklor merupakan bagian dari hasil kebudayaan suatu masyarakat. Folklor merupakan suatu tradisi yang ada dalam suatu masyarakat yang tak tertulis mengenai kesastraan, kepercayaan, upacara adat (ritual), hukum, adat kebiasaan dan sebagainya yang bersifat lokal. 
Folklor mempunyai unsur-unsur yang disebut dengan genre atau dalam bahasa Indonesia dapat diartikan sebagai bentuk. Menurut Jan Harold Brunvand, folklor dapat digolongkan ke dalam tiga kelompok besar berdasarkan tipenya:

1. Folklor lisan (verbal folklore), Folklor lisan adalah folklor yang bentuknya memang murni lisan. Bentuk (genre) folklor yang termasuk dalam kelompok ini antara lain :

1) bahasa rakyat;

2) ungkapan tradisional, seperti peribahasa, pepatah, dan pameo;

3) pertanyaan tradisional, seperti teka teki;

4) puisi rakyat, seperti pantun, gurindam, dan syair;

5) cerita prosa rakyat, seperti mitos, legenda, dan dongeng; dan

6) nyanyian rakyat.

2. Folklor sebagian lisan (partly verbal folklore),

Folklor sebagian lisan adalah folklor yang bentuknya merupakan campuran unsur lisan dan unsur bukan lisan. Bentuk-bentuk folklor yang tergolong dalam kelompok ini di antaranya adalah :

1) kepercayaan rakyat;

2) permainan rakyat;

3) teater rakyat;

4) tari rakyat;

5) adat istiadat;

6) upacara; dan

7) pesta rakyat.

3. Folklor bukan lisan (non verbal folklore). Bukan lisan adalah folklor yang bentuknya bukan lisan, walaupun cara

1) Pembuatannya diajarkan secara lisan; Kelompok ini dapat dibagi menjadi dua subkelompok, yakni yang material dan yang bukan material. Bentuk folklor bukan lisan yang tergolong material antara lain: arsitektur rakyat (bentuk rumah asli daerah, bentuk lumbung padi, dan sebagainya);

2) kerajinan tangan rakyat;

3) pakaian dan perhiasan tubuh adat;
4) makanan dan minuman rakyat; dan

5) obat-obatan tradisional.

Sedangkan, yang termasuk bukan material antara lain:

1) Gerak isyarat tradisional (gesture);

2) bunyi isyarat untuk komunikasi rakyat (misalnya kentongan tanda bahaya di Jawa atau bunyi gendang untuk mengirim berita; dan

3) musik rakyat.

\section{Tradisi Lisan}

Konsep tradisi lisan (oral tradition) hampir sama dengan istilah folklor bedanya hanya terletak pada unsur-unsur yang ditransmisikan secara lisan dan kadangkadang diikuti dengan tindakan (Hotomo, 1991:90)

Danandjaja menyatakan hal serupa bahwa tradisi lisan dan folklore dengan referensi yang relatif sama yaitu 'budaya lisan' dengan unsur kelisanan sebagai dimensi yang esensial. Dalam perjalanan sejarah setiap hasil kebudayaan dari masa lampau diwariskan secara lisan sebagai tradisi turun temurun.

Bagi sebagian masyarakat tata cara hidup mereka berupa cara berpikir bergaul,dan bersosialisasi adalah tata cara atau pengetahuan yang diperolehnya dari nenek moyangnya (generasi sebelumnya ). Tradisi itu mengikat kesatuan sosial budaya mereka. dalam setiap tradisi memliki muatan pendidikan, sosial, religi-religi sebagai harapan masyarakat pendukungnya.

\section{Peribahasa}

Suatu hasil sastra Indonesia lama yang masih hidup sampai sekarang ialah peribahasa. Berbeda dengan hasil sastra lama yang lain seperti syair, gurindam, dan mantra, peribahasa masih digunakan walaupun sudah agak jarang.

Berdasarkan pembagian folklor di atas, peribahasa termasuk kedalam folklor lisan. Menurut Carventes dalam Danandjaja, peribahasa adalah "kalimat pendek yang disarikan dari pengalaman yang panjang". 
(Bruvand dalam Danandjaja) untuk ungkapan tradisional (peribahasa) mempunyai tiga sifat hakiki yang harus diperhatikan untuk seorang yang akan meneliti yaitu :

1. peribahasa harus berupa satu kalimat ungkapan tidak cukup hanya berupa satu kata tradisional saja;

2. peribahasa ada dalam bentuk yang sudah standar; dan

3. suatu peribahasa harus mempunyai vitalitas (daya hidup) tradisi lisan, yang dapat dibedakan dari bentuk-bentuk klise tulisan yang berbentuk syair, iklan, reportase olah raga.

\section{Paribasa Sunda}

Paribasa Sunda merupakan salah satu warisan budaya nusantara dengan kata lain paribasa Sunda merupakan salah satu bagian peribahasa yang ada di nusantara. Paribasa Sunda merupakan bahasa perbandingan yang menjadi perlambang kehidupan manusia, yang bahasan dan pengucapannya yang tidak boleh diubah-ubah. Paribasa Sunda merupakan sebuah kalimat.

Ciri-ciri paribasa sunda antara lain :

1. Paribasa Sunda mempunyai sifat membandingkan, mengumpamakan.

2. Paribasa Sunda merupakan pembicaraan yang artinya bukan yang sebenarnya.

3. Paribasa Sunda berupa kalimat yang dapat membawa perasaan kepada yang orang yang diajak bicara.

4. Paribasa Sunda kalimatnya tidak bisa diubah, dikurangi, ditambah, atau dengan pengucapannya dengan bahasa halus.

Didalam paribasa Sunda dilihat dari maksud dan tujuannya dapat digolongkan menjadi tiga bagian yaitu :

\section{Paribasa wawaran luang}

Paribasa ini isinya mengungkapkan pengalaman yang suadah biasa dalam masyarakat, serta merupakan bahan perbandingan untuk tingkah laku kita.

2. Paribasa pangjurung laku hade

Dimana paribasa ini isinya
mengungkapkan untuk melakukan perilaku-perilaku yang baik yang harus dilakukan oleh kita.

3. Paribasa panyaram lampah salah

Paribasa yang isinya mengungkapkan supaya setiap orang jangan melaksanakan kelakuan-kelakuan yang tidak baik.

\section{Makna Paribasa Sunda (Pangjurung Laku Hadé)}

Menurut Kamus Besar Bahasa Indonesia (KBBI) makna merupakan pengertian yang diberikan kepada bentuk suatu kebahasaan. Makna disejajarkan dengan arti, gagasan, konsep, pernyataan, pesan, informasi, maksud, firasat, isi, dan pikiran. (Aminuddin : 50)

Makna paribasa Sunda (pangjurung laku hadé) merupakan isi yang terkandung dalam setiap paribasa Sunda (pangjurung laku hadé) yang dapat dijadikan sebagai pegangan dalam menjalankan kehidupan sehari-hari dalam masyarakat.

\section{Fungsi}

Fungsi suatu jenis puisi ditentukan oleh masyarakat pemilik tradisi lisan. Bascom (dalam Danandjaja, 2007:19) mengungkapkan fungsi foklor antara lain yaitu :

1) Sebagai sistem proyeksi (projective system), yakni sebagai alat pencermin angan-angan suatu kolektif;

2) sebagai alat pengesahan pranatapranata dan lembaga-lembaga kebudayaan;

3) sebagai alat pendidikan anak (pedagogical device); dan

4) sebagai alat pemaksa dan pengawas agar norma-norma masyarakat akan selalu dipatuhi anggota kolektifnya.

Akan tetapi, fungsi tersebut masih umum. Fungsi yang diungkapkan oleh Bascom dapat berlaku pada semua jenis folklor.

Danandjaja mengemukakan bahwa fungsi puisi rakyat antara lain sebagai berikut:

1) Alat kendali sosial

2) Untuk hiburan 
3) Untuk memulai suatu permainan

4) Untuk menekan atau menganggap orang lain

Fungsi-fungsi tersebut bisa saja hilang seiring dengan waktu. Bertahan atau tidaknyasebuah fungsi sastra lisan tergantung pada kedudukan sastra lisan itu sendiri saat itu. Fungsi-fungsi yang hilang saja tergantikan oleh fungsi lain dikarenakan berubahnya kedudukan sastra lisan yang bersangkutan di masyarakat pemiliknya.

\section{METODOLOGI PENELTIAN Metode Penelitian}

Untuk menemukan paribasa Sunda (pangjurung laku hadé) sebagai bentuk kearifan lokal dilihat dari makna dan fungsi, dengan unsur-unsur pokok yang harus ditemukan sesuai dengan butir-butir rumusan masalah, tujuan dan manfaat penelitian, maka digunakan metode penelitian kualitatif.

Penelitian kualitatif pada hakekatnya ialah mengamati orang dalam lingkungan hidupnya, berinteraksi dengan mereka, berusaha memahami bahasa dan tafsiran mereka tentang dunia sekitarnya (Nasution, $1988: 5$ ).

Metode yang digunakan dalam penelitian ini adalah metode deskriptifkualitatif. Metode deskriptif-kualitatif merupakan suatu cara yang bukan hanya bertujuan pada pengumpulan data, tetapi sampai pada tahap analisis hingga tercapai sebuah simpulan yang berdasarkan atas pertanyaan dalam penelitian.

Dengan digunakan metode kualitatif, maka data yang didapat akan lebih lengkap, lebih mendalam, kredibel, dan bermakna sehingga tujuan penelitian dapat dicapai.

\section{Data dan Sumber Data Penelitian dan Teknik Pengumpulan Data \\ Data Penelitian}

Data dalam penelitian ini adalah paribasa Sunda (pangjurung laku hadé) sebanyak 30 paribasa. Paribasa Sunda merupakan salah satu sastra lisan dalam bentuk puisi rakyat.

\section{Sumber Data Penelitian}

Paribasa Sunda (pangjurung laku hadé) yang merupakan data dalam penelitian ini diperoleh dari :

1. Data tertulis berupa paribasa-paribasa Sunda pangjurung laku hadé

2. Informasi secara lisan yang datanya dari ketua kampung yang ada di desa Cireundeu, Cimahi Selatan yakni dari bapak Asep.

\section{Teknik Penelitian}

\section{Teknik pengumpulan Data}

Teknik pengumpulan data dalam penelitian ini antara lain sebagai berikut :

1. Wawancara

Wawancara dilakukan dengan orangorang yang kompeten terhadap teks yang diteliti

a. Tetua masyarakat Kampung Cireundeu

b. Orang-orang yang faham terhadap teks

2. Observasi

Observasi dilakukan untuk memahami konteks budaya masyarakat pemilik teks. Observasi digunakan untuk mengamati secara langsung terhadap kegiatan percakapan sehari-hari masyarakat Cireundeu dalam menggunakan paribasa Sunda.

3. Daftar Pustaka

Daftar pustaka dilakukan untuk melihat, memahami dan menulis tentang paribasa Sunda (pangjurung laku hadé), yang akan dijadikan data penelitian tertulis.

\section{Instrumen Penelitian}

\section{Instrumen Pengumpulan Data}

1) Peneliti

Dalam penelitian ini, peneliti juga berkedudukan sebagai instrumen penelitian, baik dalam hal wawancara maupun observasi.

2) Daftar pertanyaan wawancara

Daftar pertanyaan wawancara memuat sejumlah pertanyaan yang diajukan kepada narasumber. Pertanyaan yang 
diajukan kepada narasumber disesuaikan dengan posisi narasumber.

\section{Format Lembar Wawancara}

\begin{tabular}{|c|c|}
\hline No & Pertanyaan \\
\hline $\begin{array}{l}2 . \\
3 . \\
4 .\end{array}$ & $\begin{array}{l}\text { Apakah paribasa sunda dikampung } \\
\text { Cireundeu masih dipakai oleh } \\
\text { masyarakatnya? } \\
\text { Apakah mereka mengetahui dalam } \\
\text { menggunakan paribasa Sunda sesuai } \\
\text { dengan konteks yang ada? } \\
\text { Apakah mereka mengetahui arti } \\
\text { paribasa Sunda (pangjurung laku hadé) } \\
\text { ? } \\
\text { Dalam situasi bagaimana biasanya } \\
\text { mereka menggunakan paribasa Sunda } \\
\text { (pangjurung laku hadé)? } \\
\text { Darimana mereka mendapatkan } \\
\text { paribasa Sunda yang biasa dipakai } \\
\text { dalam percakapan sehari-hari? }\end{array}$ \\
\hline
\end{tabular}

\section{Format Lembar Observasi Aktivitas} Kegiatan Percakapan sehari-hari Dalam Menggunakan Paribasa Sunda

\begin{tabular}{|c|c|c|c|}
\hline No & Hal yang diamati & $\mathrm{Ya}$ & Tidak \\
\hline 1. & $\begin{array}{lr}\text { Masyarakat } & \text { kampung } \\
\text { Cireundeu mempunyai } \\
\text { aktivitas percakapan } \\
\text { antara sesama keluarga } \\
\text { atau sesama orang } \\
\text { kampung. }\end{array}$ & & \\
\hline 2. & $\begin{array}{lr}\text { Masyarakat } & \text { kampung } \\
\text { Cireundeu } & \text { dalam } \\
\text { melakukan } & \text { percakapan } \\
\text { selalu } & \text { dibarengi } \\
\text { menggunakan } & \text { paribasa } \\
\text { Sunda. } & \\
\end{array}$ & & \\
\hline 3. & $\begin{array}{lr}\text { Dalam suatu keluarga di } \\
\text { masyarakat dalam } \\
\text { memberikan pepatah } \\
\text { kepada anggota } \\
\text { keluarga yang lain atau } \\
\text { kepada keluarga sesama } \\
\text { orang yang ada } \\
\text { dikampung }\end{array}$ & & \\
\hline
\end{tabular}

menggunakan paribasa Sunda (pangjurung laku had)..

3) Alat rekam data

Alat rekam data digunakan untuk merekam data-data yang dibutuhkan dalam penelitian. Alat rekam data yang digunakan antara lain :

(1) alat tulis

Alat tulis yang digunakan adalah sebuah blocknote, sebagai kertas catatan dan pena untuk mencatat.

(2) alat rekam.

Alat rekam audio digunakan untuk merekam data lisan dari narasumber langsung. Pada penelitian ini menggunkan alat alat rekam audio dengan jenis MP4

\section{Instrumen Pengolahan Data}

Dalam Pengolahan data, peneliti membutuhkan beberapa instrumen yaitu :

1) Alat rekam audio.

Alat rekam Audio dibutuhkan dalam analisis formula paribasa Sunda yang diteliti dituturkan oleh penggunana paribasa sunda. Melalui alat rekam audio ini, data rekaman yang diperoleh pada saat pengumpulan data dapat didengar.

2) Alat tulis.

Alat tulis yang digunakan adalah lembaran kertas dan pena. Alat tulis digunakan saat penganalisisan struktur terhadap teks dilakukan.

\section{Prosedur Penelitian}

Langkah-langkah yang dilakukan dalam penelitian ini adalah sebagai berikut :

\section{Tahap Persiapan}

Dalam tahap persiapan, peneliti menentukan objek penelitian. Setelah objek penelitian ditentykan, langkah selanjutnya adalah studi pustaka. Studi pustaka dilakukan untuk memlih pendekatan apa yang sesuai dengan objek yang diteliti. Selain itu, studi pustaka dilakukan guna 
menambah informasi seputar objek penelitian.

\section{Tahap Pelaksanaan}

Tahap pelaksanaan peneliti memperoleh data tertulis dari buku paribasa sunda dan data lisan dari narasumber utama. Pemerolehan data lisan dilakukan dengan perekaman. Setelah data tersebut diperoleh, maka dilakukan transkripsi data. Setelah transkripsi dilakukan, maka tahap selanjutnya adalah analisis. Adapun langkahlangkah analisisnya sebagai berikut:

1) Membaca dan menerjemaahkan teks paribasa Sunda (pangjurung laku hadé).

2) Menganalisis makna teks.

3) Menganalisis fungsi teks.

4) Menyimpulkan hasil analisis .

\section{PEMBAHASAN}

\section{Data}

Paribasa Sunda (pangjurung laku hadé)

1. Ngeduk cikur kedah mihatur nyokel jahe kedah micarek (Mengambil kencur harus bilang-bilang, mencungkil jahe harus memberitahu).

2. Sacangreud pageuh sagolek pangkek (Mengikat kuat, mengikat menjadi satu kesatuan).

3. Ulah lunca linci luncat mulang udar tina tali gadang, omat ulah lali tina purwadaksina (Jangan loncat sana sini, lepas tali rumah, awas, jangan lupa asal kita).

4. Nyaur kudu diukur nyabda kudu di unggang (Bicara harus diukur, bicara harus diteliti).

5. Kudu hade gogog hade tagog (Harus baik bahasa, baik penampilan).

6. Kudu silih asih, silih asah jeung silih asuh (Harus saling sayang, saling bertukar pikiran, saling membimbing).

7. Pondok jodo panjang baraya (Pendek jodoh, panjang persaudaraan).

8. Ulah ngaliarkeun taleus ateul (Jangan memperbanyak talas gatal).

9. Bengkung ngariung bongok ngaronyok (Bengkok berkumpul, bengkok berkumpul).
10. Bobot pangayon timbang taraju (Berat gantungan, timbangan tangga).

11. Lain palid $k u$ cikiih lain datang $k u$ cileuncang (Bukan hanyut karena air kencing, bukan datang karena aliran air hujan).

12. Kudu nepi memeh indit (Harus tiba sebelum pergi).

13. Taraje nangeuh dulang tinande (Tangga menyandar, dulang terbuka).

14. Ulah pagiri-giri calik, pagirang- girang tampian (Jangan terpisah-pisah duduk, jangan berjauh-jauhan tempat mandi).

15. Ulah ngukur baju sasereg awak (Jangan mengukur baju sesempit badan).

16. Ulah nyaliksik ku buuk leutik (Jangan menelisik dengan rambut kecil).

17. Ulah keok memeh dipacok (Jangan kalah sebelum di patuk).

18. Kudu bisa kabulu kabale (Harus bisa kesana-kemari).

19. Mun teu ngopek moal nyapek, mun teu ngakal moal ngakeul, mun teu ngarah moal ngarih (Kalau tidak kreatif tidak akan mengunyah,kalau tidak berpikir tidak akan makan, kalau tidak usaha tidak akan masak).

20. Cai karacak ninggang batu laun laun jadi dekok (Air jatuh menimpa air lamalama menjadi lubang).

21. Neangan luang tipapada urang (Mencari solusi dari sesama).

22. $\mathrm{Nu}$ lain kudu dilainkeun nu enya kudu dienyakeun (Yang salah harus disalahkan, yang benar harus dibenarkan).

23. Kudu paheuyeuk- heuyeuk leungeun paantay-antay tangan (Harus saling berpegangan tangan, mengantri tangan).

24. Ulah taluk pedah jauh tong hoream pedah anggang jauh kudu dijugjug anggang kudu diteang (Jangan menyerah karena jauh, jangan malas karena jauh, jauh harus di datangi, jauh harus di cari).

25. Ka cai jadi saleuwi kadarat jadi salogak (Ke air jadi ke sungai, ke darat jadi selubang).

26. Melak cabe jadi cabe melak bonteng jadi bonteng, melak hade jadi hade melak 
goreng jadi goreng (Menanam cabe jadi cabe, menanam mentimun jadi mentimun, menanam kebaikan jadi kebaikan menanam keburukan jadi keburukan).

27. Manuk hiber ku jangjangna jalma hirup ku akalna (Burung terbang sama sayapnya, orang hidup sama akalnya).

28. Nimu luang tina burang (Menemukan solusi dari burang).

29. Omat urang kudu bisa ngaji diri (Awas, kita harus bisa menilai diri sendiri).

30. Urang kudu jadi ajug ulah jadi lilin (Kita harus jadi cempor jangan jadi lilin).

Analisis Makna Yang Terkandung dalam Paribasa Sunda (Pangjurung Laku Hadé)

Nilai-nilai makna yang terkadung dari paribasa- paribasa Sunda (pangjurung laku hadé) sehingga menjadi suatu bentuk kearifan lokal masyarakat sunda yang harus terus dipahami, dipegang teguh untuk menjalankan kehidupan sehari-hari. Nilainilai maknanya yaitu :

1. Ngeduk cikur kedah mihatur nyokel jahe kedah micarek (Mengambil kencur harus bilang-bilang, mencungkil jahe harus memberitahu).

Makna yang terkandung adalah apabila kita akan mengambil sesuatu barang atau apapun harus meminta ijin terlebih dahulu kepada yang empunya.

2. Sacangreud pageuh sagolek pangkek (Mengikat kuat, mengikat menjadi satu kesatuan).

Makna yang terkandung dalam paribasa di atas adalah menjadi orang itu harus teguh pada pembicaraan awal, tidak pernah mengingkari janji yang telah dibicarakan.

3. Ulah lunca linci luncat mulang udar tina tali gadang, omat ulah lali tina purwadaksina (Jangan loncat sana sini, lepas tali rumah, awas, jangan lupa asal kita).

Makna yang terkandung dalam paribasa di atas adalah dalm menjalankan kehidupan sehari-hari dalam masyarakat kita harus selalu memegang etika yang ada.

4. Nyaur kudu diukur nyabda kudu di unggang (Bicara harus diukur, bicara harus diteliti).

Makna yang terkandung dalam paribasa di atas adalah apabila sedang melakukan komunikasi dengan orang lain, maka kata-kata yang akan kita keluarkan harus ditimbang-timbang terlebih dahulu agar lawan bicara kita merasa enak dan nyaman mendengarkan pembicaraan kita.

5. Kudu hade gogod hade tagog (Harus baik bahasa, baik penampilan).

Makna yang terkandung dalam paribasa di atas adalah dengan adanya penampilan kita yang baik harus diimbangi juga dengan bahasa yang baik pula. Jangan sampai penampilan baik tetapi cara berbahasa tidak sesuai dengan kedaan penampilan yang baik tadi.

6. Kudu silih asih, silih asah jeung silih asuh (Harus saling sayang, saling bertukar pikiran, saling membimbing)

Makna yang terkandung dalam paribasa di atas adalah kita harus selalu menyayangi setiap saudara, tetangga, masyarakat yang ada disekitar kita, tidak boleh saling mencela, bermusuhan, menganiaya, dan lain-lain.

7. Pondok jodo panjang baraya (Pendek jodoh, panjang persaudaraan)

Makna yang terkandung dalam paribasa di atas adalah walaupun kita perempuan atau laki-laki tidak berjodoh tetapi kita harus selalu mempunyai jiwa persaudaraan.

8. Ulah ngaliarkeun taleus ateul (Jangan memperbanyak talas gatal).

Makna yang terkandung dalam paribasa di atas adalah sebagai manusia kita tidak boleh menyebarkan isu-isu yang tidak benar, atau memfitnah orang. 
9. Bengkung ngariung bongok ngaronyok (Bengkok berkumpul, bengkok berkumpul).

Makna yang terkandung dalam paribasa di atas adalah kita harus selalu bersamasama dalam persaudaraan dalam suka dan duka.

10. Bobot pangayon timbang taraju (Berat gantungan, timbangan tangga).

Makna yang terkandung dalam paribasa di atas adalah dalam mengadili kesalahaan seseorang harus adil dan bijaksana.

11. Lain palid $k u$ cikiih lain datang $k u$ cileuncang (Bukan hanyut karena air kencing, bukan datang karena aliran air hujan).

Makna yang terkandung dalam paribasa di atas adalah apabila kita akan berangkat ke suatu tempat harus mempunyai tujuan yang jelas sebelum menglangkah.

12. Kudu nepi memeh indit (Harus tiba sebelum pergi).

Makna yang terkandung dalam paribasa di atas adalah sebelum kita melakukan sesuatu maka harus direncanakan terlebih dahulu agar tujuan kita tercapai dengan baik dan maksimal.

\section{Taraje nangeuh dulang tinande (Tangga} menyandar, dulang terbuka).

Makna yang terkandung dalam paribasa di atas adalah setiap tugas yang telah diberikan kepada kita maka harus dikerjakan dengan baik dan benar.

14. Ulah pagiri-giri calik, pagirang- girang tampian (Jangan terpisah-pisah duduk, jangan berjauh-jauhan tempat mandi).

Makna yang terkandung dalam paribasa di atas adalah kita dalam menjalankan tugas yang diberikan harus selalu dijalankan bersama-sama. Tidak boleh saling menjatuhkan karena ingin berebut kekuasaan.
15. Ulah ngukur baju sasereg awak (Jangan mengukur baju sesempit badan.

Makna yang terkandung dalam paribasa di atas adalah janganlah kita menjadi orang kikir untuk diri kita sendiri.

16. Ulah nyaliksik ku buuk leutik (Jangan menelisik dengan rambut kecil).

Makna yang terkandung dalam paribasa di atas adalah kita tidak boleh memperalat yang lemah, orang yang tidak punya kekuatan.

17. Ulah keok memeh dipacok (Jangan kalah sebelum di patuk).

Makna yang terkandung dalam paribasa di atas adalah kita tidak boleh merasa tidak bisa dalam melakukan sesuatu sebelum dilaksanakan. Kita harus selalu maju pantang untuk mundur.

18. Kudu bisa kabulu kabala (Harus bisa kesana-kemari).

Makna yang terkandung dalam paribasa di atas adalah kita harus bisa menyesuaikan diri dimanapun kita berada.

19. Mun teu ngopek moal nyapek, mun teu ngakal moal ngakeul, mun teu ngarah moal ngarih (Kalau tidak kreatif tidak akan mengunyah,kalu tidak berpikir tidak akan makan, kalau tidak usaha tidak akan masak).

Makna yang terkandung dalam paribasa di atas adalah dalam mengarungi kehidupan ini kita harus bekerja keras, karena kalau kita malas bekerja kita tidak akan dapat memenuhi kebutuhan hidup yang kita inginkan.

20. Cai karacak ninggang batu laun laun jadi dekok (Air jatuh menimpa air lamalama menjadi lubang).

Makna yang terkandung dalam puisi di atas adalah Apabila kita melakukan sesuatu yang kita anggap tidak bisa, tetapi kita kerjakan dengan tekun maka akan tercapai keberhasilannya. 
21. Neangan luang tipapada urang (Mencari solusi dari sesama).

Makna yang terkandung dalam paribasa di atas adalah kita harus belajar dari pengalaman orang lain.

22. Nu lain kudu dilainkeun nu enya kudu dienyakeun (Yang salah harus disalahkan, yang benar harus dibenarkan).

Makna yang terkandung dalam paribasa di atas adalah kita harus berbicara, bertindak atau melakukan sesuatu dengan yang sebenar-benarnya, apabila benar maka harus menyatakan benar, kalau salah maka harus nyatakan salah.

23. Kudu paheuyeuk-heuyeuk leungeun paantay-antay tangan (Harus saling berpegangan tangan, mengantri tangan).

Makna yang terkandung dalam paribasa di atas adalah kita harus bersatu bersamasama dalam mengembang tanggung jawab yang diberikan.

24. Ulah taluk pedah jauh tong hoream pedah anggang jauh kudu dijugjug anggang kudu diteang (Jangan menyerah karena jauh, jangan malas karena jauh, jauh harus di datangin, jauh harus di cari).

Makna yang terkandung dalam paribasa di atas adalah kita tidak boleh merasa pesimis dalam melakukan pekerjaan harus maju pantang mundur apapun resikonya.

25. Ka cai jadi saleuwi kadarat jadi salogak (Ke air jadi ke sungai, ke darat jadi selubang).

Makna yang terkandung dalam paribasa di atas adalah apabila dalam persahabatan atau dalam perkawinan kita harus saling menghormati, menyayangi, mengisi satu sama lain.

26. Melak cabe jadi cabe melak bonteng jadi bonteng, melak hade jadi hade melak goreng jadi goreng (Menanam cabe jadi cabe, menanam timun jadi timun, menanam kebaikan jadi kebaikan menanam keburukan jadi keburukan).

Makna yang terkandung dalam paribasa di atas adalah apa yang ditanam itulah yang dituai, kalau kita menanam kebaikan walaupun sekecil apapun akan dibalas dengan kebaikan pula, kalau kita menanam keburukan maka keburukan pula yg didapat.

\section{Manuk hiber ku jangjangna jalma hirup} ku akalna (Burung terbang sama sayapnya, orang hidup sama akalnya).

Makna yang terkandung dalam paribasa di atas adalah kita harus menggunakan akal dalam melangkah dan berbuat sesuatu yang kita inginkan, Yang Maha Kuasa menciptakan akal ini untuk kita gunakan sebagai mestinya.

28. Nimu luang tina burang (Menemukan solusi dari burang).

Makna yang terkandung dalam paribasa di atas adalah semua kejadian pasti ada hikmah/ manfaatnya apabila kita bisa menyikapinya dengan cara yang positif.

29. Omat urang kudu bisa ngaji diri (Awas, kita harus bisa menilai diri sendiri).

Makna yang terkandung dalam paribasa di atas adalah kita harus bisa mengkaji diri sendiri jangan suka menyalahkan orang lain.

30. Urang kudu jadi ajug ulah jadi lilin (Kita harus jadi lampu cempor jangan jadi lilin).

Makna yang terkandung dalam paribasa di atas adalah kita jangan sampai terbakar oleh ucapan kita, misalnya kita memberikan nasihat yagn baik kepada orang lain tapi dalam kenyataan seharihari kita terbakar oleh nasihat-nasihat yang kita berikan kepada yang lain tersebut, seperti layaknya lilin yang memberikan penerangan tapi ikut terbakar habis bersama api yang dihasilkan. 


\section{Fungsi}

Fungsi dari adanya penuturan paribasa Sunda (pangjurung laku hadé) yang dilakukan oleh masyarakat khususnya masyarakat sunda adalah ;

a. Sebagai sistem proyeksi (projective system), yakni sebagai alat pencermin angan-angan suatu kolektif. Hal ini tergambar pada kontek penuturan, yakni waktu, situasi dan orang-orang yang terlibat saat teks paribasa Sunda dituturkan. Paribasa sunda (pangjurung laku hadé) menjadi sistem proyeksi atau sebagai cermin harapan dari masyarakat dalam melakukan segala tindakantindakan, perilaku-perilaku di dunia ini dengan kebaikan.

b. Paribasa sunda (pangjurung laku hadé) merupakan alat pengesahan pranatapranata dan lembaga-lemabaga kebudayaan. Paribasa Sunda (pangjurung laku hadé) menjadi alat pengesahan sebuah kebudayaan bagi masyarakt sunda. Paribasa Sunda (pangjurung laku hadé) juga merupakan sebuah produk budaya yang dihasilkan oleh masyarakat pemiliknya yaitu masyarakat sunda.

c. Paribasa Sunda (pangjurung laku hadé) merupakan bagian dari alat pendidikan anak (pedagogical device). Paribasa Sunda (pangjurung laku hadé) banyak terkandung nilai nilai pendidikan bagi anak dintaranya.

1) Harus selalu berkata jujur;

2) harus selalu menepati janji;

3) harus mempunyai sifat mengayomi sesama;

4) selalu menjaga kebersamaan;

5) dalam melakukan sesuatu harus dipertimbangkan terlebih dahulu;

6) tidak boleh saling berebut kekuasaan;

7) berjiwa ksatria;

8) dalam melakukan sesuatu harus maju terus pantang mundur; dan

menggunakan akal dalam setiap langkah kegiatan.

\section{Hasil wawancara}

Masyarakat Kampung Cireunde dalam keseharian dalam melakukan percakapan sehari-hari menggunakan bahasa Sunda. Hasil dari wawancara dari Tetua kampung dan salah satu masyarakat di kampung Cireundeu, pertama masyarakat Kampung Cireundeu masih memakai paribasa salah satunya paribasa Sunda pangjurung laku hadé dalam melakukan percapakan, kedua, masyarkat Kampung Cireundeu dalam menggunakan paribasa Sunda ngetahui penggunaanya sesuai dengan konteks pembicaan yang digunakan. Ketiga, dalam melakukan percakapan dengan menggunakan paribasa tentunya sudah mengetahui dan memahami makna dan arti sesuai dengan konteks percakapan yang diberikan ke lawan bicaranya. Kelima, dalam percakapan dengan menggunakan paribasa sunda, masyarakat kampung Cireundeu mendapatkannya selain dari pendidikan dari sekolah, tetapi karena masyarakatnya masih menjungjung tinggi nilai-nilai kearifan lokal khususnya kebahasaan pada umumnya masyarakat Cireundeu mendapatkannya percakapan orang tua mereka sebelumnya.

\section{Hasil Observasi}

Tabel 4.32

Lembar Observasi Aktivitas Kegiatan Percakapan sehari-hari Dalam Menggunakan Paribasa Sunda

\begin{tabular}{|c|c|c|c|}
\hline No & Hal yang diamati & $\mathrm{Ya}$ & Tidak \\
\hline 1. & $\begin{array}{lr}\text { Masyarakat } & \text { kampung } \\
\text { Cireundeu mempunyai } \\
\text { aktivitas percakapan } \\
\text { antara sesama keluarga } \\
\text { atau sesama orang } \\
\text { kampung. }\end{array}$ & $\sqrt{ }$ & \\
\hline 2. & $\begin{array}{l}\text { Masyarakat kampung } \\
\text { Cireundeu dalam } \\
\text { melakukan percakapan } \\
\text { dalam keluarga atau } \\
\text { masyarakat adakalanya } \\
\text { dibarengi menggunakan }\end{array}$ & $\sqrt{ }$ & \\
\hline
\end{tabular}




\begin{tabular}{|c|c|c|}
\hline & paribasa Sunda. & \\
\hline 3. & $\begin{array}{l}\text { Dalam suatu keluarga di } \\
\text { masyarakat dalam } \\
\text { memberikan pepatah } \\
\text { kepada anggota } \\
\text { keluarga yang lain atau } \\
\text { kepada keluarga sesama } \\
\text { orang yang ada } \\
\text { dikampung } \\
\text { menggunakan paribasa } \\
\text { Sunda pangjurung laku } \\
\text { hadé.. }\end{array}$ & $\sqrt{ }$ \\
\hline
\end{tabular}

\section{SIMPULAN}

Dari paparan di atas dapat disimpulkan :

1. Nilai-nilai makna yang terkadung dari paribasa- paribasa Sunda (pangjurung laku hadé) sehingga menjadi suatu bentuk kearifan lokal masyarakat sunda yang harus terus dipahami, dipegang teguh untuk menjalankan kehidupan sehari-hari. Nilai-nilai maknanya secara keseluruhan adalah dalam melakukan suatu kegiatan yang kita lakukan haruslah berpedoman pada norma-norma yang ada dalam masyarakat tersebut.

2. Fungsi dari adanya penuturan paribasa sunda (pangjurung laku hadé) yang dilakukan oleh masyarakat khususnya masyarakat sunda adalah ;

a. Sebagai sistem proyeksi (projective system), yakni sebagai alat pencermin angan-angan suatu kolektif. Hal ini tergambar pada kontek penuturan, yakni waktu, situasi dan orang-orang yang terlibat saat teks paribasa sunda dituturkan. Paribasa sunda (pangjurung laku hadé) menjadi sistem proyeksi atau sebagai cermin harapan dari masyarakat dalam melakukan segala tindakan-tindakan, perilaku-perilaku di dunia ini dengan kebaikan.

b. Paribasa Sunda (pangjurung laku hadé) merupakan alat pengesahan pranata-pranata dan lembagalemabaga kebudayaan. Paribasa sunda (pangjurung laku hadé) menjadi alat pengesahan sebuah kebudayaan bagi masyarakt sunda. Paribasa sunda (pangjurung laku hadé) juga merupakan sebuah produk budaya yang dihasilkan oleh masyarakat pemiliknya yaitu masyarakat sunda.

c. Paribasa Sunda (pangjurung laku hadé) merupakan bagian dari alat pendidikan anak (pedagogical device). Paribasa sunda (pangjurung laku hadé) banyak terkandung nilai nilai pendidikan bagi anak dintaranya

1) Harus selalu berkata jujur;

2) harus selalu menepati janji;

3) harus mempunyai sifat mengayomi sesama;

4) selalu menjaga kebersamaan;

5) dalam melakukan sesuatu harus dipertimbangkan terlebih dahulu;

6) tidak boleh saling berebut kekuasaan;

7) berjiwa ksatria;

8) dalam melakukan sesuatu harus maju terus pantang mundur; dan

9) menggunakan akal dalam setiap langkah kegiatan.

\section{DAFTAR PUSTAKA}

1. Aminuddin. 1995. Pengantar Apresiasi Karya Sastra. Jakarta : Sinar Baru Algesindo

2. Aminuddin. 1998. Semantik Pengantar Studi tentang Makna Jakarta : Sinar Baru Bandung

3. Arikunto, Suharsimi. 2006. Manajemen Penelitian. Jakarta : Rineka Cipta

4. Danandjaja, James. 1997. Foklor Indonesia (Ilmu gossip, dongeng, dan lain-lain). Jakarta : Grafiti

5. Djamris, Edwar. 1993. Menggali Khazanah Sastra Melayu Klasik. Jakarta : balai Pustaka

6. Depdiknas. 2008. Kamus Besar Bahasa Indonesia. Pusat Bahasa. (Edisi Keempat). Jakarta : Gramedia 
7. Endraswara, Suwardi. 2011. Metodologi Penelitian Sastra-Epistimologi, Model, Teori, dan Aplikasi. Yogyakarta : CAPS

8. Fraenkel, Jack R \& Norman E Wallen. 2007. How to Design and Evaluate Research

9. Keraf Gorys. 1984. Tata Bahasa Indonesia. Jakarta : Nusa Indah

10. Rahayu Tamsyah. Budi. dkk.1996. 1000 Babasan Jeung Paribasa Sunda. Bandung : Pustaka Setia

11. Rahayu Tamsyah. Budi. dkk.1996. Kamus Lengkep Sunda-Indonesia, Indonesia-Sunda, Sunda-Sunda Bandung : Pustaka Setia
12. Ramlan, M. 2001. Sintaksis Ilmu Bahasa Indonesia. Yogyakarta, CV Karyono

13. Sugiono. 2010. Metode Penelitian Kualitatif . Bandung : Alfabeta

14. Tarigan, H.G 1992. Menulis sebagai suatu Keterampilan Berbahasa. Bandung : Angkasa

15. Taufiq Hidayat. Rachmat. dkk. 2010. Peperenian Urang Sunda. Bandung : Kiblat

Wellek\&warren. $1990 \quad$ Teori Kesusastraan. Jakarta : PT Gramedia. 